\title{
Increased ROS production and DNA damage in monocytes are biomarkers of aging and atherosclerosis
} (1) CrossMark

\author{
Thais A. Jacinto ${ }^{1 \dagger}$, Giselle S. Meireles ${ }^{2 \dagger}$, Ananda T. Dias ${ }^{1}$, Rafaela Aires ${ }^{1}$, Marcella L. Porto ${ }^{3}$, Agata L. Gava ${ }^{1,4}$, \\ Elisardo C. Vasquez ${ }^{1,2}$, Thiago Melo C. Pereira ${ }^{2,3}$, Bianca P. Campagnaro ${ }^{2 *}$ [D and Silvana S. Meyrelles ${ }^{1}$
}

\begin{abstract}
Background: New evidence demonstrates that aging and dyslipidemia are closely associated with oxidative stress, DNA damage and apoptosis in some cells and extravascular tissues. However, in monocytes, which are naturally involved in progression and/or resolution of plaque in atherosclerosis, this concurrence has not yet been fully investigated. In this study, we evaluated the influence of aging and hypercholesterolemia on serum pro-inflammatory cytokines, oxidative stress, DNA damage and apoptosis in monocytes from apolipoprotein E-deficient (apoE $\left.{ }^{-/-}\right)$mice compared with age-matched wild-type C57BL/6 (WT) mice. Experiments were performed in young (2-months) and in old (18-months) male wild-type (WT) and apoE ${ }^{-/-}$mice.
\end{abstract}

Results: Besides the expected differences in serum lipid profile and plaque formation, we observed that atherosclerotic mice exhibited a significant increase in monocytosis and in serum levels of pro-inflammatory cytokines compared to WT mice. Moreover, it was observed that the overproduction of ROS, led to an increased DNA fragmentation and, consequently, apoptosis in monocytes from normocholesterolemic old mice, which was aggravated in agematched atherosclerotic mice.

Conclusions: In this study, we demonstrate that a pro-inflammatory systemic status is associated with an impairment of functionality of monocytes during aging and that these parameters are fundamental extra-arterial contributors to the aggravation of atherosclerosis. The present data open new avenues for the development of future strategies with the purpose of treating atherosclerosis.

Keywords: apoE knockout mice, Atherosclerosis, Proinflammatory cytokines, Apoptosis

\section{Background}

Despite improvements in pharmacological and nonpharmacological interventions, atherosclerosis is still the leading cause of death in western countries $[1,2]$ and considered an epidemic disease worldwide [3]. In the last decade, many studies have provided an extraordinary progress in the understanding of this disease, and cumulative evidence shows that lipoprotein metabolism

\footnotetext{
*Correspondence: biancacampagnaro@yahoo.com.br

${ }^{\dagger}$ Thais A. Jacinto and Giselle S. Meireles contributed equally to this work

${ }^{2}$ Laboratory of Translational Physiology and Pharmacology,

Pharmaceutical Sciences Graduate Program, Vila Velha University (UVV),

Rua Mercúrio, s/n, Boa Vista 1, Vila Velha, ES 29102-623, Brazil

Full list of author information is available at the end of the article
}

disorders per se cannot sufficiently explain the development of atherosclerotic lesions [4]. Additional factors such as aging, oxidative stress, endothelial dysfunction and activation of the immune system have also been considered important modulators for the aggravation of the atherosclerotic disease [5-8]. Another important open question in this process is the involvement of key extravascular cells related with inflammation, such as the monocytes.

In conditions of hypercholesterolemia, monocytes migrate from the blood stream targeting injured vascular tissues, where these cells differentiate into macrophages [9-11]. Monocyte-derived macrophages uptake oxidized low-density lipoprotein (ox-LDL) and become lipid-rich 
foam cells, leading to the release of pro-inflammatory cytokines which in turn contributes to formation of atheroma [11]. Sequentially, into the plaques, the cholesterol crystals inhibit the macrophage autophagy process, exacerbating the inflammatory response and contributing to the defective efferocytosis [12]. This process results in the formation of unstable plaques [12].

Considering the close and dynamic contact of peripheral blood cells with the arterial wall [13, 14], an amplified systemic inflammation response is a major factor contributing to the aggravation of atherosclerosis and could predict future adverse clinical outcomes.

We have recently demonstrated in the apoE ${ }^{-/-}$mouse model of spontaneous atherosclerosis, that the concurrence of aging and hypercholesterolemia is associated with oxidative stress and DNA damage in undifferentiated bone marrow cells, which are very important for tissue maintenance and repair/regeneration [15]. Therefore, it is important to consider that peripheral blood cells play an important role in atherogenesis promoting and perpetuating the recruitment of bone marrow monocytes [16-19].

Although many studies have been conducted to evaluate various mechanisms involved in atherosclerotic disease, the effects of increased production of reactive oxygen species (ROS) in monocytes of hypercholesterolemic and aged mice has not yet been completely elucidated. The aim of the present study was to test the hypothesis that the concurrence of hypercholesterolemia and aging lead to enhanced production of oxidative stress and DNA damage in systemic monocytes.

\section{Results}

\section{Blood cells counting}

Considering that aging and atherosclerosis could influence the blood cell populations, we used flow cytometry to determine the percentage of circulating monocytes in blood. The percentage of monocytes in the apoE ${ }^{-/-}$mice was significantly augmented in both young $(11.8 \pm 0.3 \%)$ and old $(26.6 \pm 0.4 \%)$ mice compared with WT $(8.2 \pm 0.3$ and $20.4 \pm 0.4 \%$, respectively) (Fig. 1c).

\section{OGTT and biochemistry parameters}

In order to evaluate other metabolic parameters that could be affected by aging and particularly by atherosclerosis, we measured glycemia and observed that the values were similar in young and aged WT ( $76 \pm 4 \mathrm{vs.} 90 \pm 5 \mathrm{mg} /$ $\mathrm{dL}$, respectively) and apoE ${ }^{-/-}$(96 \pm 15 vs. $105 \pm 10 \mathrm{mg} /$ $\mathrm{dL}$, respectively) mice. Regarding OGTT data, no significant difference was observed between groups in WT (young: $24786 \pm 534$ vs. old: $26727 \pm 580 \mathrm{AUC}_{0-120}$ ) and apoE $^{-1-}$ (young: $24313 \pm 2261$ vs. old: $21928 \pm 2741$ AUC $0-120)$.
Serum lipid profile is represented in Fig. 1d. As expected, all the $\mathrm{apoE}^{-1-}$ groups showed an increase in non-HDL cholesterol (young: $216 \pm 36$ and old: $162 \pm 19 \mathrm{mg} / \mathrm{dL}, \mathrm{p}<0.05)$ compared with the WT mice $(31 \pm 1$ and $34 \pm 2 \mathrm{mg} / \mathrm{dL}$, respectively). Regarding HDL, a reduction was observed (young: $11 \pm 2$ and old: $10 \pm 1 \mathrm{mg} / \mathrm{dL}, \mathrm{p}<0.05)$ compared with the WT mice ( $46 \pm 1$ and $42 \pm 2 \mathrm{mg} / \mathrm{dL}$, respectively), without any change in triglycerides in all groups.

\section{Inflammation analyses}

Six cytokines that are known to be involved in inflammation were quantified by flow cytometry with the CBA system. As shown in Fig. 2, aged atherosclerotic mice exhibited a significant increase in the levels of biomarkers of inflammation IL-6 (42\%), TNF (30\%) and MCP-1 (85\%) compared to age-matched WT mice. Aging by itself caused a significant increase in the levels of IL-12 (WT: 2.6-fold; apoE ${ }^{-1-}$ : twofold, $\mathrm{p}<0.05$ ) and INF $(\mathrm{WT}$ : 2.1-fold; apoE $\mathrm{E}^{-I-}$ : twofold, $\left.\mathrm{p}<0.05\right)$. No significant difference was observed in IL-10 levels between groups.

\section{ROS production}

The production of ROS was determined by the DHE staining approach in both monocytes (Fig. 3) and in aorta sections (Fig. 4). Top panel of Fig. 3 shows a typical flow cytometry histogram of monocytes. The histogram showed a rightward shift in the log of DHE fluorescence in old compared to young WT (blue and black lines) and $\mathrm{apoE}^{-1-}$ (red and black lines) mice (Fig. 3a). As summarized in the bottom bar graph, old apoE ${ }^{-1-}$ mice exhibited a remarkable increase in ROS production (expressed in MFI) in monocytes compared with young apoE ${ }^{-1-}$ mice $(3424 \pm 129$ vs. $1682 \pm 277$ a.u., $\mathrm{p}<0.05$, respectively) and compared to age-matched WT mice $(1519 \pm 98$ vs. $508 \pm 92$ a.u., $p<0.05$, respectively, Fig. 3b). Figure 4 panels show typical images from aorta and, as expected, old apo $\mathrm{E}^{-/-}$mice exhibited notable lipid plaques which was not observed in old WT mice (Fig. 4a). Figure 4b and c shows the ROS production in aortic arch from apoE $\mathrm{E}^{-/-}$ mice compared to WT. The typical microscopic images show an augmented DHE staining in the cross sections of aorta of apoE $\mathrm{E}^{-/-}$mice compared to age-matched WT (Fig. 4b). Bottom bar graph in Fig. 4c summarizes the analysis of ROS. The old hypercholesterolemic mice show a remarkable increase in ROS production in aortic arch $(16097 \pm 395$ a.u., $\mathrm{p}<0.05)$ compared with age-matched WT (10947 \pm 459 a.u.) animals. Similarly, the aging process shows increased oxidative stress in mice's aortic arch, when comparing old and young WT $(2223 \pm 327$ a.u. $)$ and $a p o E^{-/-}(5046 \pm 670$ a.u., $\mathrm{p}<0.05)$ mice. 


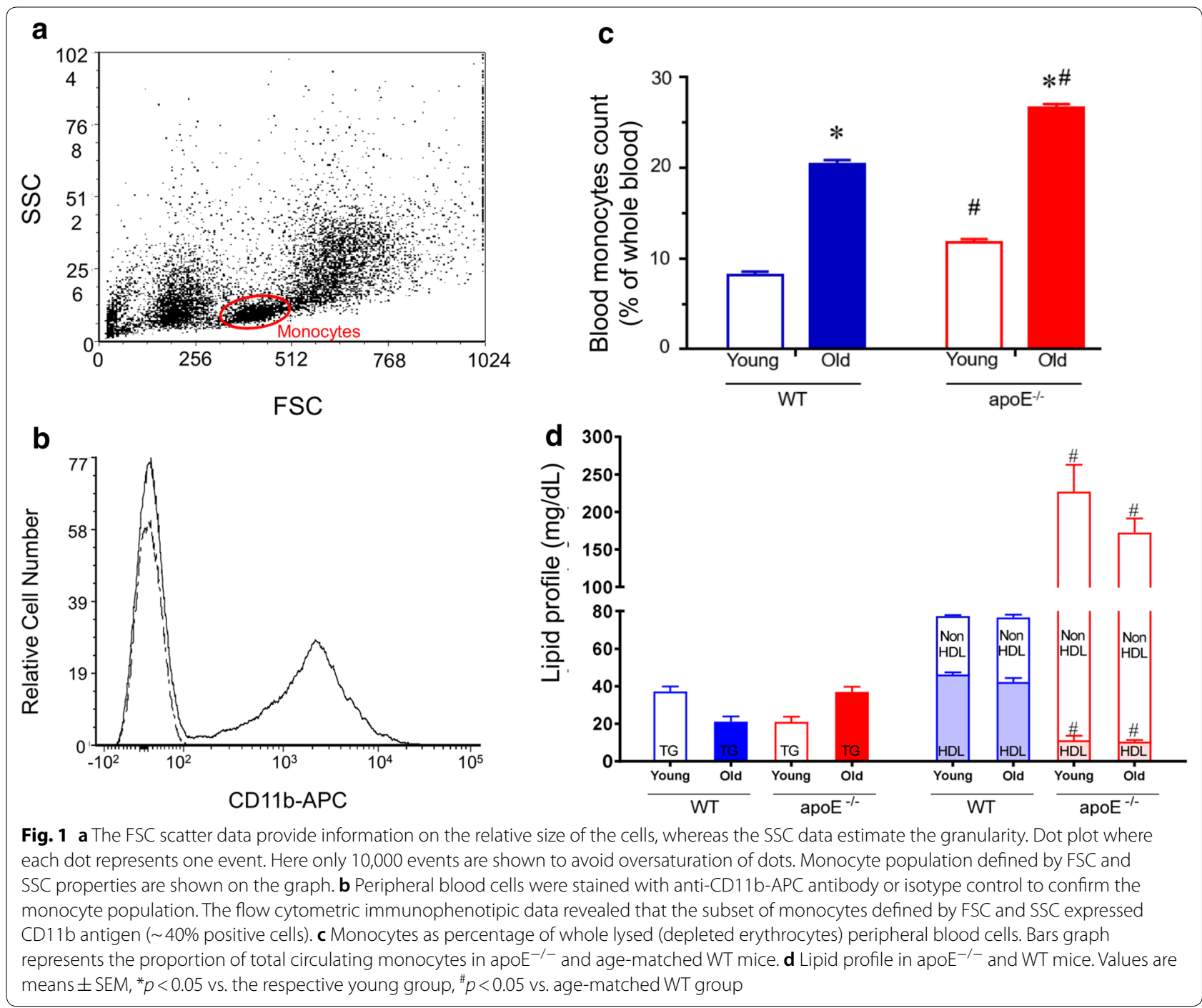

Figure $4 \mathrm{~d}$ shows typical photomicrographs of aortic arch sections stained with hematoxylin and eosin. The image of the aortic arch from aged apoE ${ }^{-1-}$ mice shows a developed plaque area, while the image for young atherosclerotic and WT mice shows no structural differences.

\section{DNA content}

Given that hypercolesterolemia increases the ROS production in apoE $\mathrm{E}^{-/-}$mice, and that this stimulus can interact with and damage the DNA, we tested the DNA fragmentation by cell permeabilization followed by PI labeling (Fig. 5). As illustrated in the DNA histograms, apoE ${ }^{-1-}$ mice showed a subtle increase in fragmented DNA in monocytes (Fig. 5a) compared to age-matched WT mice. The total fragmented DNA is summarized in Fig. 5b, confirming the augmented DNA fragmentation in atherosclerotic mice (young: $8.0 \pm 0.2$; old: $23.0 \pm 1.0 \%$, $\mathrm{p}<0.05$ ) compared to WT (young: $5.0 \pm 0.6$; old: $9.5 \pm 0.3 \%, \mathrm{p}<0.05)$ animals. In addition, aging per se was able to increase DNA damage in both WT and $\mathrm{apoE}^{-1-}$ (WT: 60\%; apoE $\mathrm{E}^{-1-}: 142 \%, \mathrm{p}<0.01$ ).

After the analysis of DNA damage, we decided to verify the statistical relationship between ROS production and DNA fragmentation. For this purpose, a correlation test was applied, which showed a significant positive correlation between these two variables in old and hypercholesterolemic animals (WT young: $r=0.65$; WT old: $r=0.84$; apoE $E^{-1-}$ young: $r=0.86$; $\mathrm{apoE}^{-1-}$ old: $\left.\mathrm{r}=0.96\right)$.

\section{Apoptosis}

Considering that during apoptosis, phosphatidylserine becomes available for annexin V binding and that PI is excluded from live cells, we evaluated the apoptosis in blood cells by flow cytometry using annexin V-FITC 



Fig. 2 Serum cytokine profile. Protein levels of pro-inflammatory cytokines in apoE ${ }^{-/-}$versus WT mice. Serum levels of IL-6 (a), TNFa (b), MCP-1 (c), INF- $\gamma(\mathbf{d})$, IL-10 (e) and IL-12 (f) were evaluated by flow cytometry. Atherosclerotic aged mice showed augmented pro-inflammatory cytokine expression compared with WT. Values are means \pm SEM, ${ }^{*} p<0.05$ vs. age-matched WT group

and PI to distinguish live from apoptotic cells. Figure 6a shows representative dot plots. The apoE ${ }^{-1-}$ animals showed a remarkable increase in apoptotic cell number compared to age-matched WT animals. Bar graphs in Fig. $6 \mathrm{~b}$ showed an increased number of apoptotic monocytes in apoE $^{-/-}$mice when compare to age-matched WT mice (young: eightfold; old: 1 , sixfold, $\mathrm{p}<0.05$ ). In addition, aging per se increased apoptotic cell number in WT (young: $1.3 \pm 0.8$; old: $34.6 \pm 1.1 \%, \mathrm{p}<0.01$ ) and atherosclerotic mice (young: $10.6 \pm 0.6$; old: $55.1 \pm 2.1 \%$, $\mathrm{p}<0.01)$.

\section{Discussion}

The present study shows, for the first time, that hypercholesterolemia and aging leads to monocytosis, oxidative stress and, consequently, genomic instability and apoptosis in monocytes of aged $\mathrm{apoE}^{-/-}$mice. We previously demonstrated in apoE $\mathrm{E}^{-/-}$mice that augmented 


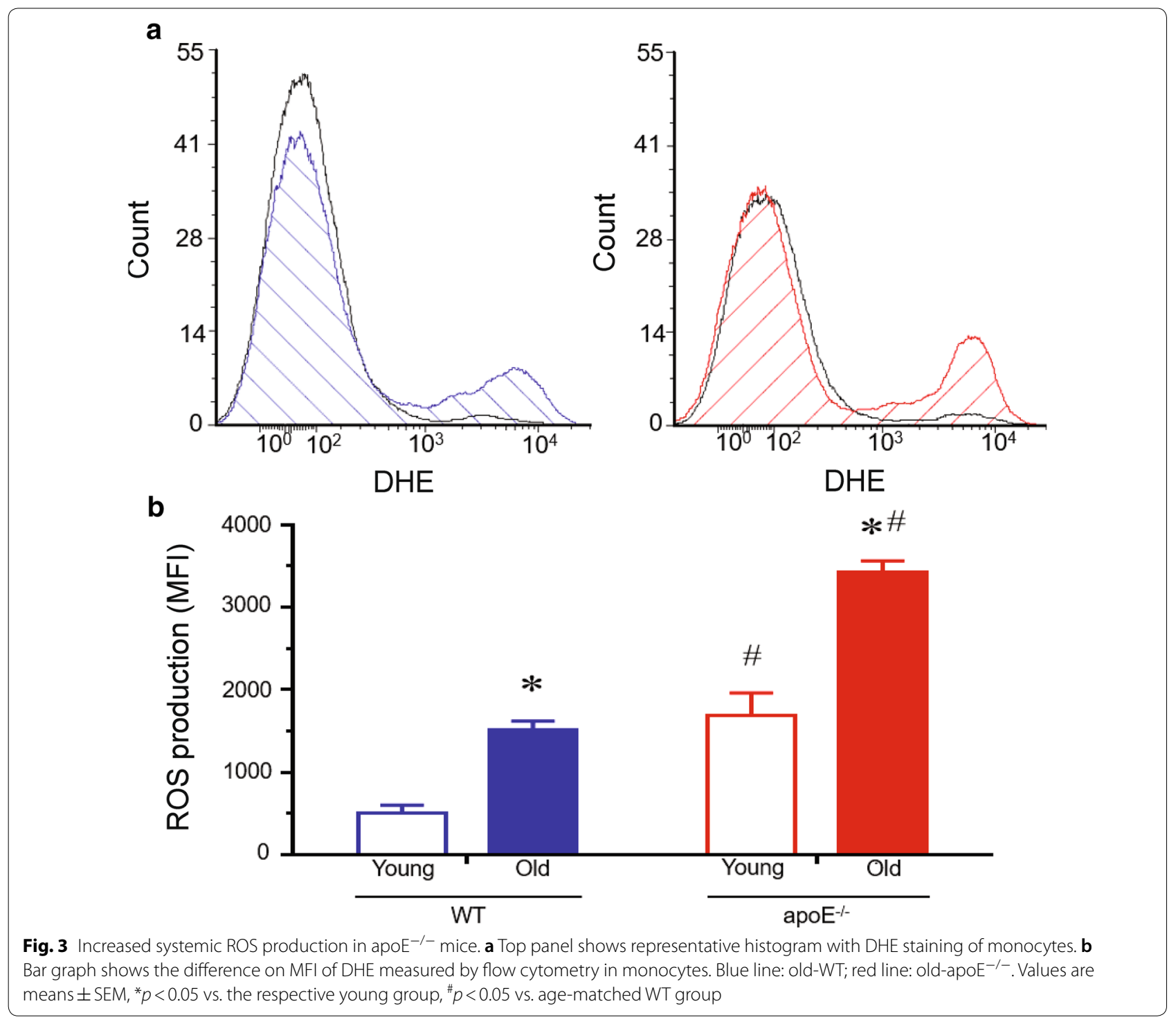

ROS production occurs in arteries, liver, bone marrow and other organs during atherogenesis [15, 20-23]. Moreover, we showed that DNA damage is an event linked with ROS production [15, 21-23], and that it is greatly aggravated by aging $[15,21]$. However, despite this, there is still no evidence of the relationship between increased oxidative stress and genomic instability in monocytes of apoE $\mathrm{E}^{-1-}$ aged mice.

As expected, and corroborating previous data from our group, apoE $\mathrm{E}^{-/-}$mice showed higher levels of nonHDL and HDL plasma cholesterol than those of the WT group [15, 20-23]. Moreover, no differences were observed in triglyceride values between groups. The typical images of the aorta (Fig. 4) reinforce the results previously obtained by us in mice of the same age, showing a difference of at least $\sim 14$-fold in lipid deposition between aged apo $\mathrm{E}^{-1-}$ and WT mice $[15,24]$. In order to exclude metabolic parameters that could be influenced by aging and, particularly, by atherosclerosis, we also measured blood glucose and OGTT and observed that the values were similar between the groups. Moreover, recent data from our laboratory demonstrated that under a normal diet, aging does not affect other biochemical profiles in the apoE $\mathrm{E}^{-1-}$ mouse [15].

Monocytes have a key role in atherosclerotic process since they are recruited from the bloodstream to the aorta wall during atherogenesis [25]. Previous studies revealed an association risk between leukocytosis and cardiovascular diseases [26-28]. In the present study we observed an increased peripheral monocytosis in 
a
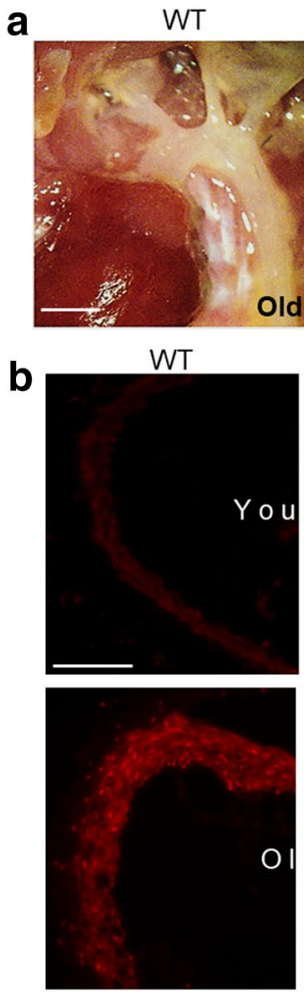

apoE $^{-/-}$

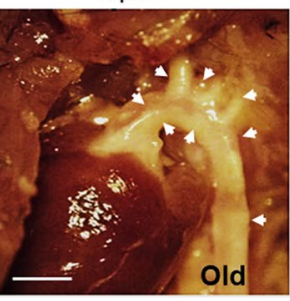

apoE

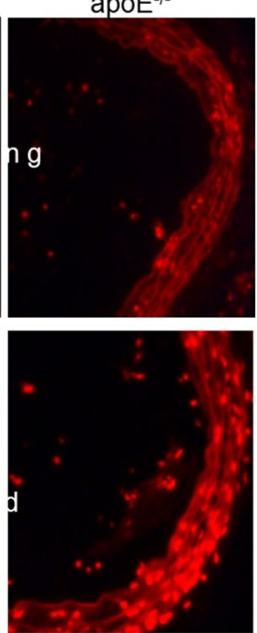

c

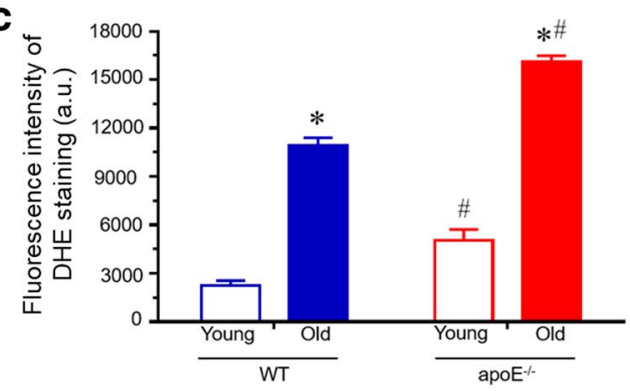

d

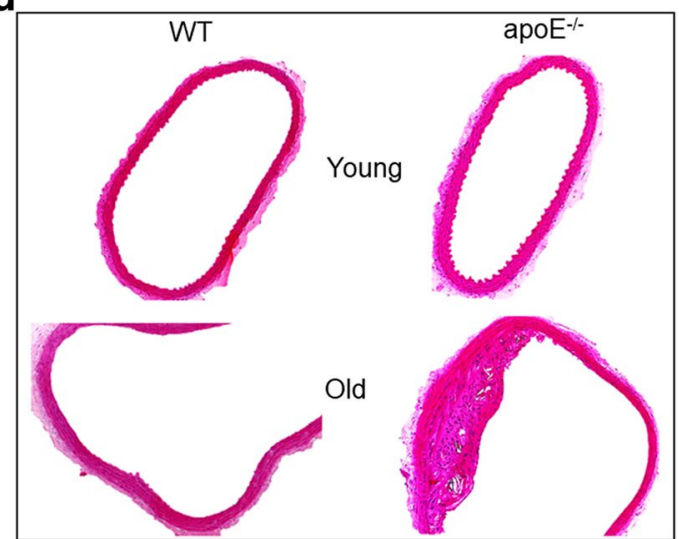

Fig. 4 a Representative photographs of mice aortic arch anatomy in situ. Atherosclerotic plaque formation is notably greater in apoE ${ }^{-/-}$mice, while no lesion was present in the age-matched WT control. Arrow heads indicates plaque deposition $(4 \times ; B a r=2 \mathrm{~mm})$. $\mathbf{b}$ DHE staining of representative aortic arch cross-sections. Atherosclerotic mice showed increased DHE-positive cells compared to WT (magnification 400x; $\mathrm{Bar}=100 \mu \mathrm{m}$ ). c Quantification of ROS production. Aging increased ROS production in aortic arch cross-section and it was aggravated through hypercholesterolemia. d Representative micrographs of aortic arch stained with hematoxylin and eosin. Values are means \pm SEM, ${ }^{* *} p<0.01$ vs. WT. ${ }^{*} p<0.05$ vs. the respective young group, ${ }^{\#} p<0.05$ vs. age-matched WT group

apoE $\mathrm{E}^{-/-}$mice and this finding is in agreement with other studies [29-32]. Previous studies suggest that hypercholesterolemia during aging may be associated with a homeostasis disruption in bone marrow [28, 33-38], leading to an increased entry of monocytes into atherosclerotic plaque $[28,39,40]$. In addition, previous reports revealed that hypercholesterolemia increased the expression of growth factors [41] and that, in this regard, apoE acts to regulate the proliferation of hematopoietic stem/ progenitor cells leading to a subsequent expansion of myeloid lineage [28]. Interestingly, this "disrupting bone marrow hypothesis" was recently confirmed in experimental apoE ${ }^{-1-}$ mice model by us [15] and by others [40, 41]. Taken together, these data corroborate the monocytosis observed in the present study, however the detailed mechanism underlying monocytosis has not yet been fully understood.

Many studies show that the progression of atherosclerosis is orchestrated and mediated by a complex network of pro-inflammatory cytokines and their antagonism results in limitation of plaque development [42-45]. An important finding of the present study was the overproduction of serum pro-inflammatory cytokines (IL-6, TNF- $\alpha$, MCP-1 and INF- $\gamma$ ) observed in aged mice, as well as in young experimental atherosclerotic models [46-48], leading to an amplification of the inflammatory cascade. Accordingly, previous data demonstrated that the expression of IL- 6 , TNF $\alpha$ and MCP- 1 is controlled by NF-кB gene expression [49-51], a signaling pathway activated by different factors, such as hemodynamic forces and oxidized lipoproteins $[45,52]$. These evidences suggest the use of pharmacological inhibitors of NF- $\mathrm{kB}$ as an alternative anti-atherosclerotic therapeutic strategy [53]. However, we cannot discard a possible involvement of other cytokines. In the near future, these serum proinflammatory biomarkers may help to predict prognosis and evaluate the response to therapy providing a relevant approach on patient care and follow-up.

Previous studies have shown that monocytes mediate inflammatory cascades and are involved in endothelial dysfunction and ROS overproduction [54-58], it is plausible to consider that monocytosis can enhance 


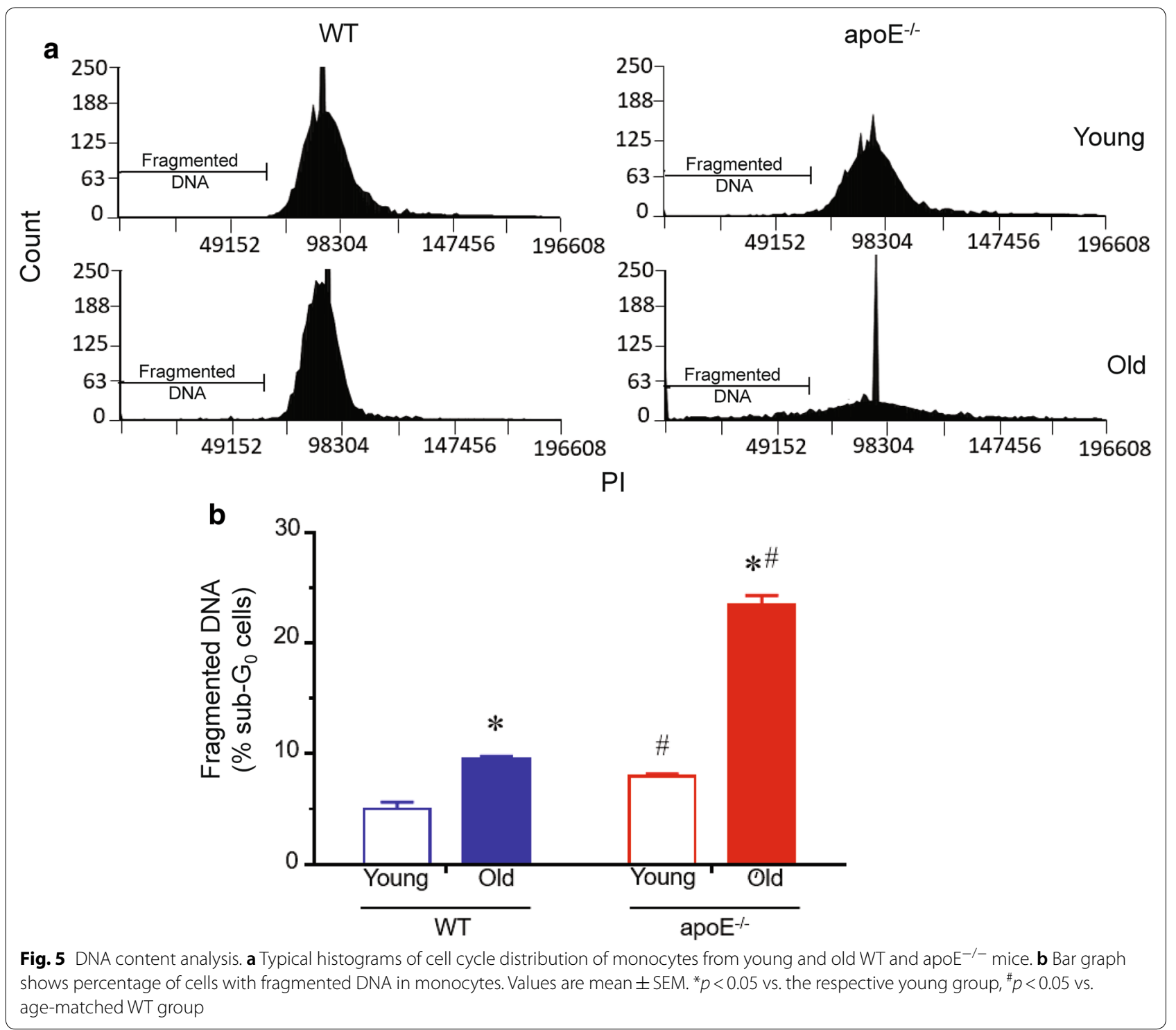

atherogenesis [59]. Cytokines contribute to the atherosclerotic disease in two phases. In the acute one, different cytokines contribute to endothelial dysfunction, expression of adhesion molecules and leukocyte diapedesis [42, 44]. In the late phase, activated leukocytes can be permanently stimulated by local cytokines, enhancing the transformation of macrophages into foam cells via scavenger receptors and cell-oxidation [17, 24, 60-62]. Cumulative data suggest that the overproduction of serum proinflammatory cytokines, associated with monocytosis in late phase of atherogenesis, may also contribute to the perpetuation of the inflammatory process and triggers extravascular disorders, as has been observed by us and others $[12,15]$.
The close relationship between inflammation and oxidative damage $[6,15,22,63]$ is supported by previous studies from our group demonstrating that virtually all cells from classical target organs of cardiovascular diseases are affected by ROS overproduction [7, 15, 20-23, $64,65]$, mainly by the NADPH oxidases, which also are the main sources of ROS in phagocytic cells [66]. The present findings support the idea that the deleterious effects of ROS are not restricted to hypercholesterolemia and that they may be enhanced by aging, can occur in classical target tissue (e.g. endothelial and smooth muscle cells, and plaque macrophages) and in peripheral blood monocytes, contributing to the progression of atherosclerosis. 

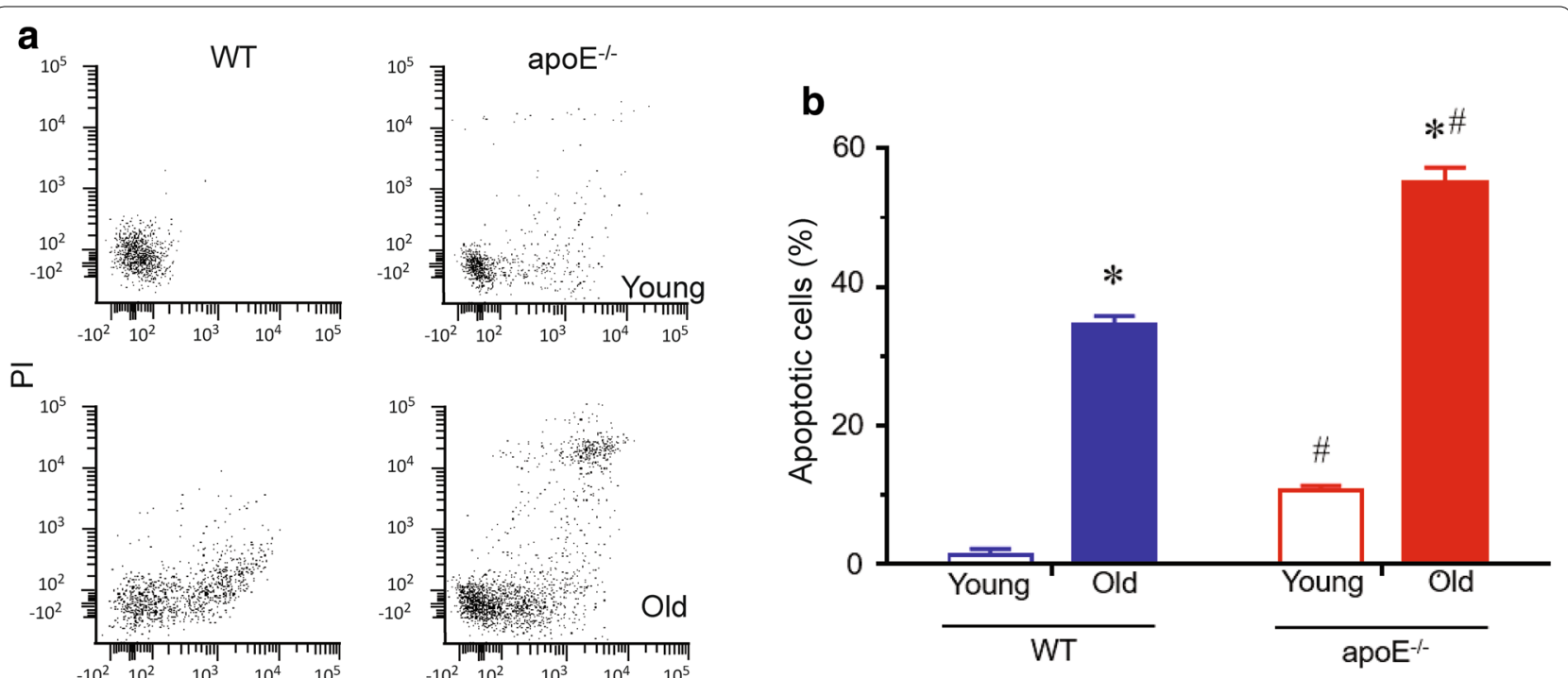

$\overline{\mathbf{\alpha}}$
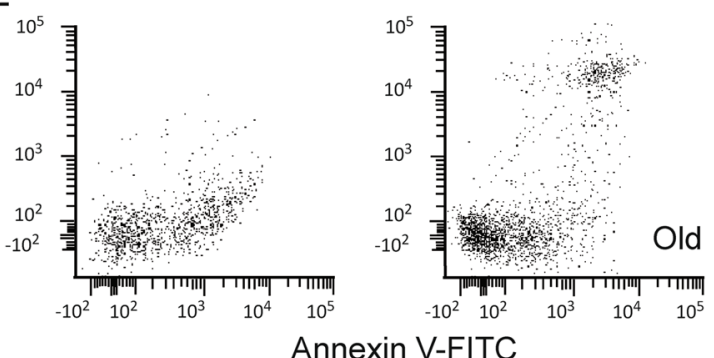

Annexin V-FITC

Fig. 6 Flow cytometric determination of apoptosis. a Representative dot-plots of Annexin $\mathrm{V}^{\mathrm{FITC}}$ and PI dual color flow cytometry for monocytes. $\mathbf{b}$ Bar graph shows average percentage of apoptotic cells $(\mathrm{Q} 2+\mathrm{Q} 4)$ from monocytes of WT and apoE ${ }^{-/}$mice. Values are mean \pm SEM. ${ }^{*} p<0.05$ vs. the respective young group, ${ }^{*} p<0.05$ vs. age-matched WT group

In the present study, we observed that the development of monocytosis in aged and in dyslipidemic mice is associated with an increased level of serum pro-inflammatory cytokines and ROS overproduction in circulating monocytes and in aorta sections. We and others have previously demonstrated that ROS overproduction may promote DNA damage through many pathways, since they are well-known genotoxins [6, 22, 23, 67-69]. The novelty of our research is the observation of an increased DNA damage in monocytes of aged and atherosclerotic animals. We demonstrated previously that ROS overproduction leads to DNA double-strand breaks and increased micronuclei formation in apoE ${ }^{-/-}$mice, confirming the genotoxic, mutagenic and cytotoxic effects of hypercholesterolemia in bone marrow cells $[15,23]$. Thus, in accordance with those previous data, our study also indicates that ROS production may proportionally contribute to DNA damage $[6,15,22,23,70,71]$.

Although it is well stablished that ROS overproduction plays a central role in cell growth, differentiation and apoptosis $[6,64,72]$, the present data provides new insights by showing increased circulating apoptotic monocytes in aged mice compared to WT mice, and that this process was aggravated by hypercholesterolemia. A reasonable explanation for this finding could be that the transmigration of monocytes is mediated by proinflammatory cytokines and, in advanced plaques, macrophage-derived monocytes are the major contributors to oxidative stress and, consequently, to the inflammatory response [73, 74]. The macrophage-derived monocytes lipid metabolism can become overwhelmed, leading to increased lipid deposition and the growth of atherosclerotic lesions [75]. We speculate that the recruitment of apoptotic monocytes to the plaque could contribute to atherosclerosis progression by the suppression of efferocytosis [12, 76-79], culminating in the retention of lipoproteins and modification of crosstalk among cytokine signaling pathway [80]. Efferocytosis of apoptotic macrophages plays an important role in the earlier stages of atherosclerosis, as it suppresses the proinflammatory signals from foam cells [81]. During aging, this process becomes compromised, leading to an amplification of the proinflammatory signals and monocytes recruitment $[82,83]$. This efferocytosis failure could be explained by the expression of CD47 antigen in the plaque cells, which impairs the recognition of apoptotic cells by efferocytes [84] and by the accumulation of oxidized LDL, which competes for apoptotic cell recognition [85].

ROS and DNA damage data suggest that the increased apoptosis of monocytes that we observed in $\mathrm{apoE}^{-1-}$ animals, contribute to the progression of atherosclerosis [79]. However, we cannot attribute all the changes to binomial aging and hypercholesterolemia as apoE gene itself may participate in the clearance of apoptotic cells remnants and stimulate a pro-inflammatory response $[86,87]$. In addition, increased ROS production is the first signal of monocytes dysfunction, and the regulation of this process is critical in the 
development of atherosclerosis [88]. The upregulation of the $\mathrm{C}-\mathrm{C}$ chemokine type 2 receptor (CCR2) $[89,90]$ and CCR5 [91] stimulates monocyte recruitment to the atherosclerotic plaques. In chronic inflammatory diseases like atherosclerosis, monocytes with macrophage-like behavior are predominant, and increase ROS production, propagating inflammation and oxidative stress [92]. Therefore, circulating monocytes could act as systemic sensors, suggesting that these cells could be used for monitoring, and even an attractive therapeutic target for the prevention or treatment of atherosclerosis.

Since all the types of cytokines were not completely evaluated, this study could possibly be a source of diagnostic bias. Last, but not least, results of this study might not be completely generalizable to other experimental models because apoE protein shows antioxidant and immune modulatory effects, as described above.

\section{Conclusions}

In conclusion, we observed that aged mice exhibited an increased systemic pro-inflammatory response associated with an impairment of functionality of monocytes, showing an augmented oxidative stress, DNA damage and apoptosis, which was aggravated by hypercholesterolemia. Therefore, our results may contribute to a better understanding of the progression of atherosclerosis due to age-related changes in circulating monocytes. The present data open new avenues for the development of future strategies for treating atherosclerosis. Further studies are needed to elucidate alternative pathways to atherosclerotic process in this mice model.

\section{Methods}

\section{Animals}

Experiments were performed in 2- and 18-month-old male wild-type C57BL/6 (WT, $\mathrm{n}=8)$ and apoE ${ }^{-1-}(\mathrm{n}=8)$ mice, bred and maintained in the animal care facility at the Laboratory of Translational Physiology in the Health Sciences Center at the Federal University of Espirito Santo, Brazil. The mice were housed in individual plastic cages with a controlled temperature $\left(22-23{ }^{\circ} \mathrm{C}\right)$ and humidity (60\%) and were exposed to a 12:12-h light-dark cycle. All mice were fed a standard chow diet and had access to water ad libitum. All experimental procedures were performed in accordance with the guidelines for the care and handling of laboratory animals as recommended by the National Institutes of Health $(\mathrm{NIH})$, and study protocols were previously approved by the Institutional Animal Care Committee (CEUA-Emescam, Protocol \# 014/2011).

\section{Oral glucose tolerance test (OGTT)}

To evaluate insulin resistance in all groups, fasted mice were administered orally with $2 \mathrm{~g}$ of glucose $/ \mathrm{kg}$ body weight, and blood glucose was checked at regular intervals $(0,15,30,60$, and $120 \mathrm{~min})$ through tail blood extraction. For this purpose, the animals were placed in a restrainer and the tail section was covered with a clean gauze swab with lidocaine cream (4\%) in the last $4 \mathrm{~mm}$. After $2 \mathrm{~min}$, the anaesthetic was removed with ethanol solution (70\%) and the last $1 \mathrm{~mm}$ of the tip of the tail was then removed using sterilized surgical scissors. The tail was then gently massaged to ensure an adequate blood flow. The total glucose response versus time was evaluated by area under the curve (AUC) using Prism software (Prism 6.0, GraphPad Software, Inc., San Diego, CA, USA).

\section{Biochemical parameters}

Venous blood was collected by intracardiac puncture from the right ventricle of $\mathrm{C} 57$ and apo $\mathrm{E}^{-/-}$mice euthanized with a sodium thiopental overdose $(100 \mathrm{mg} /$ $\mathrm{kg}$, i.p.) to determine serum concentrations of glucose, triglycerides, total plasma cholesterol, high density lipoprotein (HDL) and non-HDL, using an automatic spectrophotometry analyzer supplied by collaborators of a clinical analysis laboratory (Tommasi Laboratory, Vitoria, ES, Brazil). Non-HDL levels were calculated by subtracting HDL from total serum cholesterol.

\section{Isolation of blood cells and flow cytometry}

Blood samples collected were mixed with lysing Buffer $1 \times$ (Amersham Biosciences, Piscataway, NJ) for $5 \mathrm{~min}$ at $37{ }^{\circ} \mathrm{C}$ to remove erythrocyte. Cell suspension was centrifuged for $10 \mathrm{~min}$ at $1200 \mathrm{rpm}$, supernatant was discarded and the pellet washed in phosphate-buffered saline (PBS) plus 10\% Fetal Bovine Serum (FBS) for $10 \mathrm{~min}$ at $1200 \mathrm{rpm}$. Cells were collected and resuspended in $1 \mathrm{~mL}$ PBS with 10\% FBS. Erythrocytedepleted intact blood cells were counted and analyzed by flow cytometry. For specific leukocytes population analysis, in a cell population scatter plot displaying the FSC ( $x$-axis) and SSC (y-axis) of lysed whole blood graph, monocytes were gated for flow cytometry analysis as shown in Fig. 1a. The different physical properties of monocytes allow them to be distinguished from cellular contaminants. For the confirmation of monocytes population among whole blood cells, the samples were incubated with allophycocyanin (APC)-labeled antimouse CD11b (BD: Becton-Dickinson Biosciences, San Jose, CA, USA) (Fig. 1b). After blood collection, the 
atherosclerotic-associated macroscopic changes in aortic arch were visually determined (Fig. 4a).

\section{Macroscopic and microscopic evaluation of aortic arch plaque}

For the macroscopic evaluation, after blood collection the animals were perfused, the aorta was delicately isolated, and the connective tissue was removed to allow visualization of any the atherosclerotic-associated changes in the aortic arch, particularly plaque deposition (Fig. 4a).

In addition, for microscopic visualization of the aortic arch, mice were euthanized (sodium thiopental, $100 \mathrm{mg} /$ $\mathrm{Kg}$, IP) and perfused via the left ventricle with phosphate-buffered saline (PBS, $\mathrm{pH} 7.4 ; 01 \mathrm{M}$ ) followed by a fixative solution of formaldehyde (4\%). The aortic arch was dissected, removing removing the connective tissue. After resting overnight in the fixative solution, the aortic arch were embedded in methyl methacrylate resin and $5 \mu \mathrm{m}$ sections were prepared. The samples were stained with hematoxylin and eosin, and images were captured with a video camera (AxioCam ERc5s, Carl Zeiss, Germany) with $40 \times$ magnification.

\section{Analyses of cytokines with flow cytometric bead-based assay}

The cytometric bead array (CBA) mouse inflammation kit (BD) employs a series of particles with discrete fluorescence intensities to simultaneously detect multiple soluble analytes, which were measured in particlebased immunoassay through the sensitivity of amplified fluorescence detection by flow cytometry. In the CBAMouse Inflammation Kit (CBA-Mouse) system from BD, six bead populations with distinct fluorescence intensities are coated with capture antibodies specific for IL-6, IL-10, MCP-1, INF- $\gamma$, TNF, and IL-12p70 proteins [6]. The six bead populations are mixed together to form the BD CBA which is resolved in a red channel of a flow cytometry. The capture beads, PE-conjugated detection antibodies, and recombinant standards or test samples are incubated together to form sandwich complexes. Cytokines levels were measured in plasma, according to the manufacturer's instructions (BD). For these analyses, a typical forward and side scatter gate was set to exclude aggregates; a total of 5000 events in the gate were analyzed using FACSCanto II and FACSDiva Software (BD). Samples were quantified by comparison with standard curves of recombinant mice cytokines using FCAP Array software. The results were expressed as $\mathrm{pg} / \mathrm{mL}$.

\section{Measurement of intracellular reactive oxygen species}

The ROS analysis was performed by flow cytometry as previously described $[6,15,20,21]$. Given its ability to freely permeate cell membranes, dihydroethidium (DHE) has extensively been used to monitor ROS production. To estimate the ROS production, approximately $100 \mu \mathrm{L}$ of erythrocyte-depleted intact blood cells were incubated with $20 \mu \mathrm{L}$ of DHE $(160 \mu \mathrm{M})$ for $30 \mathrm{~min}$ at $37^{\circ} \mathrm{C}$ in the dark to load the cells with the dye. For positive control, samples were treated with $10 \mu \mathrm{M}$ doxorubicin for $5 \mathrm{~min}$ to create oxidative stress without cell toxicity. Cells incubated with ethanol were used as the negative control. Cells were then washed, resuspended in PBS, and maintained on ice for immediate acquisition by flow cytometry (BD). Data were analyzed using the FACSDiva software (BD), and overlay histograms were constructed using the FCS Express software. For fluorescence quantification, samples were acquired in duplicate, and 10,000 events were registered from each sample. Intensity of specific fluorescence was expressed as the median fluorescence intensity (MFI), from the average of at least three repeated experiments (a.u.).

In addition, to detect ROS production in aorta, unfixed frozen sections from the artery were cut in 7 - $\mu \mathrm{m}$-thick sections and mounted on gelatin coated glass slides. Samples were incubated with DHE $(2 \mu \mathrm{mol} / \mathrm{L})$ in a modified Krebs's solution (containing $20 \mathrm{mM}$ HEPES), in a light-protected humidified chamber at $37{ }^{\circ} \mathrm{C}$ for $30 \mathrm{~min}$ [22]. The fluorescence intensity was quantified by a blind investigator using a fluorescence microscope (Nikon Eclipse TI, Nikon Instruments Inc., Melville, NY, USA). Data is expressed in arbitrary units.

\section{DNA content analysis}

Cell cycle distribution was determined by flow cytometry analysis of the DNA content. Briefly, erythrocytedepleted intact blood cells were incubated with $200 \mu \mathrm{L}$ of staining solution $(20 \mathrm{mg} / \mathrm{mL}$ RNAse A, $500 \mathrm{mg} / \mathrm{mL}$ propidium iodide [PI], 1\% Triton X-100) for $30 \mathrm{~min}$ at $4{ }^{\circ} \mathrm{C}$, in the dark. Then, cells were washed, centrifuged for $10 \mathrm{~min}$ at $1200 \mathrm{rpm}$, and resuspended in PBS. Samples were acquired in triplicate and 10,000 events were used for each measurement. The cell cycle profile was determined using a FACSCanto II flow cytometer. For determination of DNA content, samples were acquired in triplicate and 10,000 events were used for each measurement. The fragmented low-molecular weight DNA can be observed to the left of interphasic DNA (2n) cells peak [20]. Data analysis was performed by the FACSDiva software.

\section{Apoptosis}

Apoptotic cells were determined by the loss of plasma membrane integrity, which was characterized by the translocation of the phospholipid phosphatidylserine from the inner to the outer leaflet allowing the binding of the annexin $\mathrm{V}$ protein to cells with exposed 
phosphatidylserine. $200 \mu \mathrm{L}$ erythrocyte-depleted intact blood cells were resuspended in binding buffer $1 \times$ (10 mmol HEPES, NaOH, pH 7.4, $140 \mathrm{mmol} \mathrm{NaCl}$, $2.5 \mathrm{mmol} \mathrm{CaCl}_{2}$ ). Then, $100 \mu \mathrm{L}$ of this solution were transferred to a new tube and incubated with $5 \mathrm{~mL}$ of Annexin V-FITC and $5 \mathrm{~mL}$ of PI for $15 \mathrm{~min}$ at room temperature $\left(25{ }^{\circ} \mathrm{C}\right)$ in the dark, using a commercial kit according to the manufacturer's instructions (BD). Finally, $400 \mu \mathrm{L}$ of $1 \times$ binding buffer was added to each tube and the samples analyzed by a FACSCanto II flow cytometer (BD) within $1 \mathrm{~h}$. All data analyses were performed using FACSDiva analysis software (BD). For quantification of apoptotic cells, samples were acquired in triplicate and 10,000 events were used for each measurement and data expressed as the percentage of positive cells. The percentage of cells was determined in $\mathrm{Q}_{1}$ (Annexin $\mathrm{V}^{\mathrm{FITC}-/ \mathrm{PI}+}$, damaged cells), $\mathrm{Q}_{2}$ (Annexin $\mathrm{V}^{\mathrm{FITC}+1}$ ${ }^{\mathrm{PI}+}$, end stage apoptotic cells), $\mathrm{Q}_{3}$ (AnnexinV $\mathrm{F}^{\mathrm{FITC}-/ \mathrm{PI}-}$, viable cells), and $\mathrm{Q}_{4}$ (Annexin $\mathrm{V}^{\mathrm{FITC}+/ \mathrm{PI}-}$, early apoptotic cells) $[6,15,20,21]$. The apoptotic rate of cells undergoing apoptosis was determined as the percentage of $\mathrm{Q}_{2}+\mathrm{Q}_{4}$.

\section{Statistical analysis}

All data are expressed as mean \pm SEM. The normality (Gaussian distribution) of the variables was previously analyzed using the Kolmogorov-Smirnov test. When this test was significant, the statistical analysis was performed using two-way analysis of variance (ANOVA) followed by Tukey's post hoc test. The analyses were performed using Prism software (Prism 7, GraphPad Software, Inc., San Diego, CA, USA). The differences between means were considered significant when $\mathrm{p}<0.05$.

\section{Abbreviations \\ apoE ${ }^{-/-}$: apolipoprotein E knockout mice; CBS: cytometric bead-array; DHE: dihydroethidium; FACS: fluorescence activated cell sorting; FBS: fetal bovine serum; FITC: fluorescein isothiocyanate; FSC: forward scatter; IL: interleukine; INF: interferon; i.p.: intraperitoneal; MCP: monocyte chemoattractant protein; MFI: median fluorescence intensity; NF-kB: nuclear factor kappa b; PBS: phosphate-buffered saline; PI: propidium iodide; ROS: reactive oxygen species; SSC: side scatter; TNF: tumor necrosis factor; WT: wild type.}

\section{Authors' contributions}

TAJ and GSM isolated the blood cells and performed flow cytometry data acquisition. ATD and RA performed biochemical and histologic analysis. $M L P$ and BPC performed the flow cytometry data analysis. ECV and TMCP performed the critical revision of the manuscript. BPC and SSM performed the conception, study's design, supervision and critical revision of the manuscript. All authors read and approved the final version of the manuscript.

\section{Author details}

${ }^{1}$ Laboratory of Translational Physiology, Health Sciences Center, Federal University of Espirito Santo (UFES), Vitoria, Brazil. ${ }^{2}$ Laboratory of Translational Physiology and Pharmacology, Pharmaceutical Sciences Graduate Program, Vila Velha University (UVV), Rua Mercúrio, s/n, Boa Vista 1, Vila Velha, ES 29102-623, Brazil. ${ }^{3}$ Federal Institute of Education, Science and Technology
(IFES), Vila Velha, ES, Brazil. ${ }^{4}$ Division of Nephrology, McMaster University, Hamilton, ON, Canada.

\section{Acknowledgements}

The authors would like to thank National Council for Scientific and Technological Development (CNPq) and Foundation of Research Support and Innovation of Espírito Santo (FAPES).

\section{Competing interests}

The authors declare that they have no competing interests.

\section{Availability of data and materials}

The datasets supporting the conclusion of this article are not deposited in publicly available repositories or presented in the main manuscript or additional supporting files, because if a reader wants to look at the individual datasets, which are in Excel, Prism, FCS Express, etc., the reader can send an email to the researcher asking for this additional information.

\section{Consent for publication}

Not applicable.

\section{Ethics approval and consent to participate}

All experimental procedures were performed in accordance with the guidelines for the care and handling of laboratory animals as recommended by the National Institutes of Health $(\mathrm{NIH})$, and study protocols were previously approved by the Institutional Animal Care Committee (CEUA-Emescam, Protocol \# 014/2011).

Funding

SSM is supported by CNPq (307584/2015-1). BPC is supported by CNPq (445736/2014-3). ECV is supported by CNPq (303001/2015-1). TMCP is supported by CNPq (445080/2014-0).

\section{Publisher's Note}

Springer Nature remains neutral with regard to jurisdictional claims in published maps and institutional affiliations.

Received: 10 April 2018 Accepted: 31 Auqust 2018

Published online: 05 September 2018

\section{References}

1. Rudolf J, Lewandrowski KB. Cholesterol, lipoproteins, high-sensitivity c-reactive protein, and other risk factors for atherosclerosis. Clin Lab Med. 2014. https://doi.org/10.1016/j.cll.2013.11.003.

2. Libby P, Bornfeldt KE, Tall AR. Atherosclerosis: successes, surprises, and future challenges. Circ Res. 2016;118(4):531-4.

3. Herrington W, Lacey B, Sherliker P, Armitage J, Lewington S. Epidemiology of atherosclerosis and the potential to reduce the global burden of atherothrombotic disease. Circ Res. 2016;118(4):535-46.

4. Geng YJ, Jonasson L. Linking immunity to atherosclerosis: implications for vascular pharmacology-a tribute to Göran K. Hansson. Vasc Pharmacol. 2012. https://doi.org/10.1016/j.vph.2011.11.001.

5. Libby P, Ridker PM, Hansson GK. Leducq transatlantic network on atherothrombosis. Inflammation in atherosclerosis: from pathophysiology to practice. J Am Coll Cardiol. 2009. https://doi.org/10.1016/j. jacc.2009.09.009.

6. Porto ML, Rodrigues BP, Menezes TN, Ceschim SL, Casarini DE, Gava AL, et al. Reactive oxygen species contribute to dysfunction of bone marrow hematopoietic stem cells in aged C57BL/6J mice. J Biomed Sci. 2015. https://doi.org/10.1186/s12929-015-0201-8.

7. Leal MA, Balarini CM, Dias AT, Porto ML, Gava AL, Pereira TM, et al. Mechanisms of enhanced vasoconstriction in the mouse model of atherosclerosis: the beneficial effects of sildenafil. Curr Pharm Biotechnol. 2015;16(6):517-30.

8. Tousoulis D, Oikonomou E, Economou EK, Crea F, Kaski JC. Inflammatory cytokines in atherosclerosis: current therapeutic approaches. Eur Heart J. 2016. https://doi.org/10.1093/eurheartj/ehv759. 
9. Woollard KJ, Geissmann F. Monocytes in atherosclerosis: subsets and functions. Nat Rev Cardiol. 2010. https://doi.org/10.1038/nrcar dio.2009.228

10. Gerhardt T, Ley K. Monocyte trafficking across the vessel wall. Cardiovasc Res. 2015. https://doi.org/10.1093/cvr/cvv147.

11. Kzhyshkowska J, Gudima A, Moganti K, Gratchev A, Orekhov A. Perspectives for monocyte/macrophage-based diagnostics of chronic inflammation. Transfus Med Hemother. 2016. https://doi. org/10.1159/000444943.

12. Viola J, Soehnlein O. Atherosclerosis - a matter of unresolved inflammation. Semin Immunol. 2015. https://doi.org/10.1016/j. smim.2015.03.013.

13. Yao L, Heuser-Baker J, Herlea-Pana O, Barlic-Dicen J. Bone marrow endothelial progenitors in atherosclerotic plaque resolution. Organogenesis. 2013. https://doi.org/10.4161/org.24433.

14. Yao Y, Tsirka SE. Monocyte chemoattractant protein-1 and blood-brain barrier. Cell Mol Life Sci. 2014. https://doi.org/10.1007/s00018-013-1459-1.

15. Tonini CL, Campagnaro BP, Louro LP, Pereira TM, Vasquez EC, Meyrelles SS. Effects of aging and hypercholesterolemia on oxidative stress and DNA damage in bone marrow mononuclear cells in apolipoprotein E-deficient mice. Int J Mol Sci. 2013. https://doi.org/10.3390/ijms14023325.

16. Meyrelles SS, Peotta VA, Pereira TM, Vasquez EC. Endothelial dysfunction in the apolipoprotein E-deficient mouse: insights into the influence of diet, gender and aging. Lipids Health Dis. 2011. https://doi. org/10.1186/1476-511X-10-211.

17. Vasquez EC, Peotta VA, Gava AL, Pereira TM, Meyrelles SS. Cardiac and vascular phenotypes in the apolipoprotein E-deficient mouse. J Biomed Sci. 2012. https://doi.org/10.1186/1423-0127-19-22.

18. Knorr M, Münzel T, Wenzel P. Interplay of NK cells and monocytes in vascular inflammation and myocardial infarction. Front Physiol. 2014. https:// doi.org/10.3389/fphys.2014.00295.

19. Patzelt J, Verschoor A, Langer HF. Platelets and the complement cascade in atherosclerosis. Front Physiol. 2015. https://doi.org/10.3389/fphys .2015 .00049 .

20. Balarini CM, Leal MA, Gomes IBS, Pereira TMC, Gava AL, Meyrelles SS, et al. Sildenafil restores endothelial function in the apolipoprotein $E$ knockout mouse. JTransl Med. 2013. https://doi.org/10.1186/1479-5876-11-3.

21. Dalboni SP, Campagnaro BP, Tonini CL, Vasquez EC, Meyrelles SS. The concurrence of hypercholesterolemia and aging promotes DNA damage in apoliprotein E-deficient mice. Open J Blood Dis. 2012;2(3):51-5.

22. Rodrigues BP, Campagnaro BP, Balarini CM, Pereira TM, Meyrelles SS, Vasquez EC. Sildenafil ameliorates biomarkers of genotoxicity in an experimental model of spontaneous atherosclerosis. Lipids Health Dis. 2013. https://doi.org/10.1186/1476-511X-12-128.

23. Bernardes FP, Batista AT, Porto ML, Vasquez EC, Campagnaro BP, Meyrelles SS. Protective effect of sildenafil on the genotoxicity and cytotoxicity in apolipoprotein E-deficient mice bone marrow cells. Lipids Health Dis. 2016. https://doi.org/10.1186/s12944-016-0268-6.

24. Pereira TM, Nogueira BV, Lima LC, Porto ML, Arruda JA, Vasquez $E C$, et al. Cardiac and vascular changes in elderly atherosclerotic mice: the influence of gender. Lipids Health Dis. 2010. https://doi. org/10.1186/1476-511X-9-87.

25. Hilgendorf I, Swirski FK, Robbins CS. Monocyte fate in atherosclerosis. Arterioscler Thromb Vasc Biol. 2015. https://doi.org/10.1161/ATVBA HA.114.303565.

26. Coller BS. Leukocytosis and ischemic vascular disease morbidity and mortality: is it time to intervene? Arterioscler Thromb Vasc Biol. 2005;25(4):658-70.

27. Lee YJ, Shin YH, Kim JK, Shim JY, Kang DR, Lee HR. Metabolic syndrome and its association with white blood cell count in children and adolescents in Korea: the 2005 Korean National Health and Nutrition Examination Survey. Nutr Metab Cardiovasc Dis. 2010;20(3):165-72. https://doi. org/10.1016/j.numecd.2009.03.017.

28. Murphy AJ, Akhtari M, Tolani S, Pagler T, Bijl N, Kuo CL, et al. ApoE regulates hematopoietic stem cell proliferation, monocytosis, and monocyte accumulation in atherosclerotic lesions in mice. J Clin Invest. 2011. https ://doi.org/10.1172/JCl57559.

29. Swirski FK, Libby P, Aikawa E, Alcaide P, Luscinskas FW, Weissleder R, et al. Ly-6Chi monocytes dominate hypercholesterolemia-associated monocytosis and give rise to macrophages in atheromata. J Clin Invest. 2007:117:195-205.
30. Swirski FK, Nahrendorf M. Leukocyte behavior in atherosclerosis, myocardial infarction, and heart failure. Science. 2013. https://doi.org/10.1126/ science.1230719.

31. Tacke F, Alvarez D, Kaplan T, Jakubzick C, Spanbroek R, Llodra J, et al. Monocyte subsets differentially employ CCR2, CCR5, and CX3CR1 to accumulate within atherosclerotic plaques. J Clin Invest. 2007;1 17:185-94.

32. Du W, Wong C, Song Y, Shen H, Mori D, Rotllan N, et al. Age-associated vascular inflammation promotes monocytosis during atherogenesis. Aging Cell. 2016. https://doi.org/10.1111/acel.12488.

33. Han KH, Han KO, Green SR, Quehenberger O. Expression of the monocyte chemoattractant protein-1 receptor CCR2 is increased in hypercholesterolemia. Differential effects of plasma lipoproteins on monocyte function. J Lipid Res. 1999:40(6):1053-63.

34. Bobryshev YV. Monocyte recruitment and foam cell formation in atherosclerosis. Micron. 2006;37(3):208-22.

35. Gomes AL, Carvalho T, Serpa J, Torre C, Dias S. Hypercholesterolemia promotes bone marrow cell mobilization by perturbing the SDF-1:CXCR4 axis. Blood. 2010. https://doi.org/10.1182/blood-2009-08-240580.

36. Pathansali R, Smith N, Bath P. Altered megakaryocyte-platelet haemostatic axis in hypercholesterolaemia. Platelets. 2001;12(5):292-7.

37. Spyridopoulos I, Erben Y, Brummendorf TH, Haendeler J, Dietz K, Seeger $\mathrm{F}$, et al. Telomere gap between granulocytes and lymphocytes is a determinant for hematopoetic progenitor cell impairment in patients with previous myocardial infarction. Arterioscler Thromb Vasc Biol. 2008. https ://doi.org/10.1161/ATVBAHA.107.160846.

38. Nahrendorf M, Swirski FK. Lifestyle effects on hematopoiesis and atherosclerosis. Circ Res. 2015. https://doi.org/10.1161/CIRCRESAHA.116.303550.

39. Swirski FK, Pittet MJ, Kircher MF, Aikawa E, Jaffer FA, Libby P, et al. Monocyte accumulation in mouse atherogenesis is progressive and proportional to extent of disease. Proc Natl Acad Sci U S A. 2006;103(27):10340-5.

40. Tie G, Messina KE, Yan J, Messina JA, Messina LM. Hypercholesterolemia induces oxidant stress that accelerates the ageing of hematopoietic stem cells. J Am Heart Assoc. 2014. https://doi.org/10.1161/JAHA.113.000241.

41. Yvan-Charvet L, Pagler T, Gautier EL, Avagyan S, Siry RL, Han S, et al. ATPbinding cassette transporters and HDL suppress hematopoietic stem cell proliferation. Science. 2010. https://doi.org/10.1126/science.1189731.

42. Ait-Oufella $H$, Taleb S, Mallat Z, Tedgui A. Recent advances on the role of cytokines in atherosclerosis. Arterioscler Thromb Vasc Biol. 2011. https:// doi.org/10.1161/ATVBAHA.110.207415.

43. Zhang H, Wu LM, Wu J. Cross-talk between apolipoprotein E and cytokines. Mediators Inflamm. 2011;2011:949072.

44. Conti P, Shaik-Dasthagirisaeb Y. Atherosclerosis: a chronic inflammatory disease mediated by mast cells. Cent Eur J Immunol. 2015. https://doi. org/10.5114/ceji.2015.54603.

45. Buckley ML, Ramji DP. The influence of dysfunctional signaling and lipid homeostasis in mediating the inflammatory responses during atherosclerosis. Biochim Biophys Acta. 2015. https://doi.org/10.1016/j.bbadi S.2015.04.011.

46. Roselaar SE, Daugherty A. Apolipoprotein E-deficient mice have impaired innate immune responses to Listeria monocytogenes in vivo. J Lipid Res. 1998;39(9):1740-3.

47. Huang M, Pang $X$, Karalis K, Theoharides TC. Stress-induced interleukin-6 release in mice is mast cell-dependent and more pronounced in Apolipoprotein E knockout mice. Cardiovasc Res. 2003;59(1):241-9.

48. McNeill E, Channon KM, Greaves DR. Inflammatory cell recruitment in cardiovascular disease: murine models and potential clinical applications. Clin Sci (Lond). 2010;118(11):641-55.

49. Stokes KY, Clanton EC, Clements KP, Granger DN. Role of interferongamma in hypercholesterolemia-induced leukocyte-endothelial cell adhesion. Circulation. 2003;107(16):2140-5.

50. Ohta H, Wada H, Niwa T, Kirii H, Iwamoto N, Fujii H, et al. Disruption of tumor necrosis factor-alpha gene diminishes the development of atherosclerosis in ApoE-deficient mice. Atherosclerosis. 2005;180(1):11-7.

51. Collins T, Cybulsky MI. NF-kappaB: pivotal mediator or innocent bystander in atherogenesis? J Clin Invest. 2001;107(3):255-64.

52. Pamukcu B, Lip GY, Shantsila E. The nuclear factor-kappa B pathway in atherosclerosis: a potential therapeutic target for atherothrombotic vascular disease. Thromb Res. 2011. https://doi.org/10.1016/j.throm res.2011.03.025. 
53. Yamamoto Y, Gaynor RB. IkappaB kinases: key regulators of the NFkappaB pathway. Trends Biochem Sci. 2004;29(2):72-9.

54. Lee CD, Folsom AR, Nieto FJ, Chambless LE, Shahar E, Wolfe DA. White blood cell count and incidence of coronary heart disease and ischemic stroke and mortality from cardiovascular disease in African-American and White men and women: atherosclerosis risk in communities study. Am J Epidemiol. 2001;154(8):758-64.

55. Weber C, Zernecke A, Libby P. The multifaceted contributions of leukocyte subsets to atherosclerosis: lessons from mouse models. Nat Rev Immunol. 2008. https://doi.org/10.1038/nri2415.

56. Zernecke A, Bot I, Djalali-Talab Y, Shagdarsuren E, Bidzhekov K, Meiler S, et al. Protective role of CXC receptor $4 / C X C$ ligand 12 unveils the importance of neutrophils in atherosclerosis. Circ Res. 2008;102(2):209-17.

57. Clarke MC, Bennett MR. Cause or consequence: what does macrophage apoptosis do in atherosclerosis? Arterioscler Thromb Vasc Biol. 2009. https ://doi.org/10.1161/ATVBAHA.108.179903.

58. Heidt T, Sager HB, Courties G, Dutta P, Iwamoto Y, Zaltsman A, et al. Chronic variable stress activates hematopoietic stem cells. Nat Med. 2014 https://doi.org/10.1038/nm.3589.

59. Woollard KJ, Geissmann F. Monocytes in atherosclerosis: subsets and functions. Nat Rev Cardiol. 2010. https://doi.org/10.1038/nrcar dio.2009.228

60. Schleicher E, Friess U. Oxidative stress, AGE, and atherosclerosis. Kidney Int Suppl. 2007;106:S17-26.

61. Vasquez EC, Peotta VA, Meyrelles SS. Cardiovascular autonomic imbalance and baroreflex dysfunctionin the apolipoprotein E-deficient mouse. Cell Physiol Biochem. 2012. https://doi.org/10.1159/000277623.

62. Libby P, Hansson GK. Inflammation and immunity in diseases of the arterial tree: players and layers. Circ Res. 2015. https://doi.org/10.1161/CIRCR ESAHA.116.301313.

63. Cesari M, Kritchevsky SB, Leeuwenburgh C, Pahor M. Oxidative damage and platelet activation as new predictors of mobility disability and mortality in elders. Antioxid Redox Signal. 2006;8(3-4):609-19.

64. Campagnaro BP, Tonini CL, Doche LM, Nogueira BV, Vasquez EC, Meyrelles SS. Renovascular hypertension leads to DNA damage and apoptosis in bone marrow cells. DNA Cell Biol. 2013. https://doi.org/10.1089/ dna.2013.2065

65. Dias AT, Rodrigues BP, Porto ML, Gava AL, Balarini CM, Freitas FP, et al. Sildenafil ameliorates oxidative stress and DNA damage in the stenotic kidneys in mice with renovascular hypertension. J Transl Med. 2014. https ://doi.org/10.1186/1479-5876-12-35

66. Babior BM, Lambeth JD, Nauseef W. The neutrophil NADPH oxidase. Arch Biochem Biophys. 2002;397(2):342-4 (Review. PubMed PMID: 11795892)

67. Folkmann JK, Loft S, Møller P. Oxidatively damaged DNA in aging dyslipidemic ApoE ${ }^{-/-}$and wild-type mice. Mutagenesis. 2007;22(2):105-10.

68. Pacher P, Szabó C. Role of poly(ADP-ribose) polymerase 1 (PARP-1) in cardiovascular diseases: the therapeutic potential of PARP inhibitors. Cardiovasc Drug Rev. 2007;25(3):235-60.

69. Dizdaroglu M. Oxidatively induced DNA damage and its repair in cancer. Mutat Res Rev Mutat Res. 2015. https://doi.org/10.1016/j.mrrev .2014.11.002.

70. Zhang B, Davidson MM, Hei TK. Mitochondria regulate DNA damage and genomic instability induced by high LET radiation. Life Sci Space Res (Amst). 2014;1:80-8.

71. Fimognari C. Role of oxidative RNA damage in chronic-degenerative diseases. Oxid Med Cell Longev. 2015. https://doi.org/10.1155/2015/358713.

72. Finkel T. Oxidant signals and oxidative stress. Curr Opin Cell Biol. 2003; 15:247-54

73. Moore K, Sheedy F, Fisher E. Macrophages in atherosclerosis: a dynamic balance. Nat Rev Immunol. 2013. https://doi.org/10.1038/nri3520.

74. de Villiers WJ, Smart EJ. Macrophage scavenger receptors and foam cell formation. J Leukoc Biol. 1999;66(5):740-6.

75. Libby P. Inflammation in atherosclerosis. Nature. 2002:420:868-74.
76. Singh RB, Mengi SA, Xu YJ, Arneja AS, Dhalla NS. Pathogenesis of atherosclerosis: a multifactorial process. Exp Clin Cardiol. 2002;7(1):40-53.

77. Tabas I. Macrophage death and defective inflammation resolution in atherosclerosis. Nat Rev Immunol. 2010. https://doi.org/10.1038/nri2675.

78. De Lorenzo BH, Godoy LC, Novaes e Brito RR, Pagano RL, Amorim-Dias MA, Grosso DM, Lopes JD, Mariano M. Macrophage suppression following phagocytosis of apoptotic neutrophils is mediated by the S100A9 calcium-binding protein. Immunobiology. 2010. https://doi.org/10.1016/j. imbio.2009.05.013.

79. Van Vré EA, Ait-Oufella H, Tedgui A, Mallat Z. Apoptotic cell death and efferocytosis in atherosclerosis. Arterioscler Thromb Vasc Biol. 2012. https ://doi.org/10.1161/ATVBAHA.111.224873.

80. Ferracini M, Rios FJ, Pecenin M, Jancar S. Clearance of apoptotic cells by macrophages induces regulatory phenotype and involves stimulation of CD36 and platelet-activating factor receptor. Mediators Inflamm. 2013. https://doi.org/10.1155/2013/950273.

81. Tabas I. Consequences and therapeutic implications of macrophage apoptosis in atherosclerosis: the importance of lesion stage and phagocytic efficiency. Arterioscler Thromb Vasc Biol. 2005;25(11):2255-64.

82. Tabas I. Macrophage death and defective inflammation resolution in atherosclerosis. Nat Rev Immunol. 2010;10(1):36-46. https://doi.org/10.1038/ nri2675.

83. Linton MF, Babaev VR, Huang J, Linton EF, Tao H, Yancey PG. Macrophage apoptosis and efferocytosis in the pathogenesis of atherosclerosis. Circ J. 2016:80(11):2259-68.

84. Kojima Y, Volkmer JP, McKenna K, Civelek M, Lusis AJ, Miller CL, Direnzo D, Nanda V, Ye J, Connolly AJ, Schadt EE, Quertermous T, Betancur P, Maegdefessel L, Matic LP, Hedin U, Weissman IL, Leeper NJ. CD47-blocking antibodies restore phagocytosis and prevent atherosclerosis. Nature. 2016. https://doi.org/10.1038/nature18935.

85. Gillotte-Taylor K, Boullier A, Witztum JL, Steinberg D, Quehenberger O. Scavenger receptor class $B$ type I as a receptor for oxidized low density lipoprotein. J Lipid Res. 2001;42(9):1474-82.

86. Grainger DJ, Reckless J, McKilligin E. Apolipoprotein E modulates clearance of apoptotic bodies in vitro and in vivo, resulting in a systemic proinflammatory state in apolipoprotein E-deficient mice. J Immunol. 2004;173(10):6366-75.

87. Weber C, Soehnlein O. ApoE controls the interface linking lipids and inflammation in atherosclerosis. J Clin Invest. 2011. https://doi. org/10.1172/JCl60457.

88. Short JD, Downs K, Tavakoli S, Asmis R. Protein thiol redox signaling in monocytes and macrophages. Antioxid Redox Signal. 2016. https://doi. org/10.1089/ars.2016.6697.

89. Tacke F, Alvarez D, Kaplan TJ, Jakubzick C, Spanbroek R, Llodra J, Garin A, Liu J, Mack M, van Rooijen N, Lira SA, Habenicht AJ, Randolph GJ. Monocyte subsets differentially employ CCR2, CCR5, and CX3CR1 to accumulate within atherosclerotic plaques. J Clin Invest. 2007. https://doi. org/10.1172/JCI28549.

90. Sennlaub F, Auvynet C, Calippe B, Lavalette S, Poupel L, Hu SJ, Dominguez E, Camelo S, Levy O, Guyon E, Saederup N, Charo IF, Rooijen NV, Nandrot E, Bourges JL, Behar-Cohen F, Sahel JA, Guillonneau X, Raoul W, Combadiere C. CCR2 ${ }^{+}$monocytes infiltrate atrophic lesions in age-related macular disease and mediate photoreceptor degeneration in experimental subretinal inflammation in $\mathrm{C} \times 3 \mathrm{Cr} 1$ deficient mice. EMBO Mol Med 2013. https://doi.org/10.1002/emmm.201302692.

91. Combadière C, Potteaux S, Rodero M, Simon T, Pezard A, Esposito B, Merval R, Proudfoot A, Tedgui A, Mallat Z. Combined inhibition of CCL2, CX3CR1, and CCR5 abrogates Ly6C(hi) and Ly6C(lo) monocytosis and almost abolishes atherosclerosis in hypercholesterolemic mice. Circulation. 2008. https://doi.org/10.1161/CIRCULATIONAHA.107.745091.

92. Karwaciak I, Gorzkiewicz M, Bartosz G, Pulaski L. TLR2 activation induces antioxidant defence in human monocyte-macrophage cell line models. Oncotarget. 2017. https://doi.org/10.18632/oncotarget.17342. 